\title{
Education in Prison or The Applied Art of "Correctional" Deconstructive Learning Peter Collins
}

$\mathrm{I}_{\mathrm{c}}^{\mathrm{an}}$

am not entirely sure how to go about detailing the way I see the

Correctional Service of Canada (CSC) undermining educational potential or their systemic methodology of rendering people useless through mindless institutionalized existence. There are just so many ways in which CSC conduct underlines the contradictions and failures of meaningful education in the prison system. It feels ridiculous to even begin to try and explain the failures as they appear so obvious, so huge and so loud as I look at the years unfolding behind and in front of me. Education is such a broad and complex issue that spreads across life and the prison environment in so many ways. Without reservation it is clear that education takes place in the prison environment in addition to and in spite of the activities formally labelled 'education'. We learn from everything, no matter what. The real questions are what are we learning from the prison experience, what effect is it having and what ripples (tsunami) can we expect to touch (ravage) our shores in the future? For context, I have decided to share some of my intended and unintended educational experiences.

\section{Growing UP}

When I arrived in prison, I came as a 20 year old who had been on my own more or less since the age of 12 or 13 , so I had very little schooling excluding a hard knocks diploma from the back alley curriculum. I had a chip on my shoulder that obscured my perspective, much like many prisoners I have met over the years. At that early point in my life, I also felt that I possessed infallible insight into my own problems and everyone else's. It came as a considerable shock to me a little later in life to find that I had developed a distinctly flawed take on the world, and a somewhat narrow and self-serving closed mind. I was never wrong about anything. I also never voluntarily accepted any responsibility for any of my issues and problems. I have since learnt that I had a lot to learn and that is still the case.

As I reflect upon CSC and myself, I can see that the Correctional Service of Canada has suffered and continues to suffer the same problems I had. However, I grew up and as I grew up, I challenged myself to keep trying to accept my personal responsibilities. On the other hand, CSC continues to labour under a ridiculous culture of denial and a corporate lack of accountability. The system wields a distinct lack of insight, while being convinced they are right about everything. 
In my early teen years, I had acquired the stance that everyone else was to blame - at least in some way - for my problems in life. My teenage sense of moral outrage and entitlement was reinforced by horrible things that happened in my young life. I was quick to blame my predicament on others, especially those in authority. It was difficult to come to terms with the fact that I was the main author of most of my personal tragedies. Every problem was perceived as confirmation that the system and those who worked in it were against me, if not out to get me. It took a lot of struggling before common sense and maturity allowed me to develop a wider and more realistic perspective. I have a long complex history in the prison context and while I accept my responsibility for many of my problems and shortcomings, I know that many of the problems are products of the broken and inherently ineffective system, in part due to the obstructionist efforts of certain decision-makers. I understand that many apathetic, angry, unhappy and some considerably unbalanced people work in the prison system. It would seem that most prison workers fail to conduct or are not capable of conducting an in-depth analysis of what their occupation is doing, and why it is destined to be the constant and predictable social failure that it is.

With the help of friends and family I began to develop useful and balanced insight. With these changes I developed the skill of learning from my mistakes. I began to look at my problems, failures, and mistakes more as challenges or obstacles and set backs, which I had to think my way around and work harder to solve or overcome. There is a personal and intellectual honesty required to face anything in life. Prison is no different. As a prisoner you need to look at the reality of your situation and deal with the facts and circumstances. You will survive better if you can remain flexible, and open to new ideas and opportunities. All of the many problems I have faced over the last quarter century of imprisonment have allowed me to learn something new. In those lessons I have improved everything related to my world. Although truth be told, some of the lessons have taken longer than others to sink in and there is still a natural resistance to abandoning the known for the unknown, but we all deal with that which we have to deal with.

\section{Correctional Failure and Labels}

The idea that Correctional Service of Canada is against the education of prisoners is a tangible concept rife with tantalizing, if inexplicable, complexities. I am painfully aware of CSC resisting tooth and nail all of my educational pursuits, but I am also witness to their facilitating, albeit 
grudgingly, the post-secondary efforts of other prisoners. I recognize that my outspoken and public observations about the flawed nature of the prison system have generated a pervasive and official reactive inclination toward shutting me up and shutting me down at almost any and every turn. I am sure this is not an experience exclusive to me but I am not sure how many prisoners in Canada generate much critical review - audio, graphic and written - directed at the prison system. The majority seem to come from the United States of America. It is probably more accurate to consider that the prison-industrial complex has developed extremely effective "divide, conquer and then keep separated" agendas, which keeps prisoner activists effectively shut off from the world and therefore silent. I also note that the prison system ${ }^{1}$ has developed extremely effective methods of keeping prisoners co-opted, scared or distracted and thereby effectively neutered.

There are many subtle ways in which the system "naturally" scares and shuts people up or stunts normal human development and selfvalidation; for example, through institutionalization and through fostering a dependency upon the judgement and validation of others. There is an insidious labelling process that at once validates the prison system and invalidates prisoners as defective. They call us "offenders" as if this is all we are and all we ever will be, contributing to the internalization of a carceral master status (Goffman, 1963). They call us "inmates" as if we are in a hospital and they are going to make us better. They call the cages they lock us in cells, rooms or residencies to sanitize what is going on. They assign us "Correctional Treatment Plans" as if they are treating us for a condition that they will cure. They call what they are doing "corrections" to distract people from the harsh and relentless truth of the punishment going on in prisons. They give guards titles like "correctional workers" for the same legitimizing and distracting purposes. They label "the Hole" the "Environmental Control Area" in order to legitimize the punitive nature of long-term segregation. The criminal justice system stigmatizes people who come into contact with it by reducing their identities to critical, demeaning categories. Erving Goffman's (1963) work speaks to the inherent short-sightedness of the system which can only conceive of or interact with prisoners according to criminalized and medicalized labels.

Other complicit players in the label game are the co-opted criminologists, psychologists and psychiatrists who all too willingly jump on board the tragic but lucrative incarceration game. The labels these professionals apply to prisoners are based upon extensive coopted or prison-based clinical and statistical research. This psy-sciences 
group that seek to 'pathologize' prisoners rely upon coercively imposed, and therefore naturally unreliable tests upon an imprisoned population with high rates of illiteracy and functional illiteracy. The culmination of which results in prison decision-makers taking passive managerial roles and pointing to statistical rates of recidivism to deny prisoners release opportunities, blinding "them to a more proactive approach" (Hart et al., 2007). Critical scholarship also confirms that risk assessment models long favoured by correctional officials and social agencies to predict the likelihood that a convicted prisoner will re-offend are "fraught with problems and give a false sense of security" (ibid).

Dr. Robert Hare (1970), after paying an illiterate group of impoverished and addicted prisoners to participate in a series of testing came-up with the Psychopathy Check List revised (PCL-R) (Maden, 2003). This scheme is used by CSC to deny parole or lower security transfers if the prisoner receives a high score. These high scores have also been used to deny prisoners access to treatment programs on the premise that programming might make it worse (ibid).

We have learnt to accept these labels as legitimate, and thereby accept and perpetuate a deceptive education which validates a destructive fallacy. I cannot count the times I have heard a prisoner embrace a label thrust upon themselves, at once lamenting about being rated with such a damaging status and complaining about how all their efforts were overlooked. It is obvious to me that the abstract and fluid benchmarks of the prisons system place little to no consideration on the prisoner's efforts to improve their lives, their situation, their future and indeed themselves. Still we prisoners - out of necessity - seek to know how to change the institutionally and statistically based label. How indeed? It is, after all, impossible to question the correctional psychic-fortunetellers and tarot card reading networks. It is a faultless, self-justifying system reinforced by the narrow minded, short sighted "get-tough-oncrime" authoritarian agenda spreading across the political landscape. Truly the media, politicians, and government criminal justice and prison bureaucracies have learnt how to sway public opinion with sensationalized fear mongering.

\section{The Snake Eats Itself}

It was with considerable thought that I chose the title of this paper, Education in Prison or The Applied Art of "Correctional" Deconstructive Learning. I settled on this title after a laborious fifteen seconds. I thought it was at once suitably confusing and contradictory. I wanted to 
encapsulate the Orwellian nature of the prison corporate worlds and their predisposition to generate the appearance of an educational system, while simultaneously either demolishing the prisoners' social skills and other natural or earned abilities while also crushing personal motivations and / or simply failing to provide any meaningful educational opportunities. I argue that the system's built in failure factors have deep and enduring roots that feed off themselves. Like a snake eating itself, the self-perpetuating desire to punish people is a long unfolding human trait which flourishes unfettered in the social, criminal justice and prison context.

There is a schizoid predisposition for the prison-industrial complex to at once celebrate rehabilitation and pretend to incorporate learning opportunities, while on the other hand removing tangible educational opportunities. It is an exploitive and manipulative endeavour embraced and jettisoned as the political climate dictates. If called to task about not providing enough educational or rehabilitative opportunities, the prison system claims the need for cash infusions and more staff. However, when provided, the new cash is invariably siphoned off into security based endeavours as the ever consumptive CSC is ravenous for more fences, chains, walls and guns.

As reduced educational and recreational opportunities predictably translate into prisoner unrest or violence, the system then claims they need more cash and more security to deal with the unruly prisoners. As the years have gone by, I have seen a marked reduction in recreational funding and reductions in post-secondary education. I have seen the introduction and then removal of computers from prisoners' allowable cell effects. It is reasonable to recognize that long-term prisoners will be computer illiterate in society's computer age. It seems clear that this policy is indicative of the extremely narrow range of possible futures and employment opportunities that CSC envisions for those under its control. The notion that a prisoner could excel in more creative and technical sectors of the workforce seems quite foreign to CSC and to other prison agencies. What other purpose does this serve than to potentially hamstring released prisoners?

\section{Resisting the Education Blockade}

As an activist, I have been involved in helping my fellow prisoners with learning to read, write and speak English on a variety of levels at different periods over my sentence, in an effort to be useful. In the late 1980s, I was involved in a tutoring initiative put on by Frontier College. After I received their (non-CSC) training and certification, I began to 
tutor Vietnamese prisoners learning English as a second language (ESL). As time went by, I noticed that the guys I was working with who could not put a sentence together - verbal or written - were being passed by the Millhaven prison school at Grade 9 and 10 levels. This was clearly a statistical scam perpetrated by the school for some kind of funding manipulation - a statistical slight of hand which still occurs today. I resigned as a tutor and while I continued to work with prisoners on the cell block, I refused to be a party to that kind of official fraud.

I long ago noticed a distinct silence in release planning for prisoners and set about writing a book to help provide a basic strategy for prisoners to follow to improve the likelihood of receiving parole and hopefully staying out of prison. I held weekly seminars in the lifers group meeting room, but the prison's "Social Development Department" banned me from the room and ordered me to stop helping other prisoners with their release planning. Apparently they feared I might be politicizing prisoners - which I was not - and that it would make more work for CSC as more prisoners were applying for parole, temporary passes and transfers which I did. The Parole Planning book was recently banned from CSC prisons. It seems the reason can be attributed to the above comments and the organization's resistance to prisoners acquiring or sharing knowledge with each other about the prison experience. It is clear that the result, if not the intention, creates or further exemplifies the anti-education backdrop. It almost goes without saying that most of the people in prison have arrived in the corrupting confines of the prison experience through some violation of the social contract. But just what is it that we as a supposedly enlightened society intend to do with prisoners once we have commandeered their lives and placed them in cages? As was stated by the Daubney Commission Report (1988)

It is now generally recognized that imprisonment has not been effective in rehabilitating or reforming offenders, has not shown to be a strong deterrent, and has achieved only temporary public protection and uneven retribution... The use of imprisonment as a main response to a wide variety of offences against the law is not a tenable approach in practical terms.

In this light, we need to ask ourselves three questions as prisoners, as citizens and as a society: 1) what are we teaching in prisons?; 2) what are prisoners learning from their experiences?; and 3) do we learn from our mistakes?

Consistent to the corrosive prison legacy is the predisposition of the prison guard's sub-cultural sense of misplaced personal offence 
and outrage towards prisoners. Even as guards have sought to establish a professional status, they have been unable to shed the true nature of prison and what it does to people, both guard and prisoner. The frightening implications of the 1971 Stanford Experiment ${ }^{4}$ (Zimbardo, 2008 ) as it relates to an angry work force with aggressive, abusive, and self-interested constituents should remain front and center to any dialogue about prison. The desire to intellectually neuter the general prison population remains desirable for prison administrators, bureaucrats, guards, and opportunistic politicians who exploit a frightened and apathetic public. We are all being led down the path, quite unquestioningly, toward harsher prison conditions as we have seen in the 2008 Canadian federal election campaign. As prison guard unions, police associations and victim's rights groups begin to acquire higher levels of sophistication, they lobby more effectively to achieve their desired punitive and restrictive ends. There is little to no reliance upon social science evidence, and all major decisions seem to be reactionary and draconian. Prime Minister Stephen Harper highlighted his disdain for empirical evidence when rejecting professional criticism of his party's crime bills which seek to impose life- 25 sentences on children as young as 14 years old, criticism which he attributed to an out of touch elite living in an "ivory tower" (Whittington, 2008).

It is without reservation that I recognize prison to be the worst classroom on the planet. Prison is inherently degrading, painful and caustic. The education earned by the subjugated, punished and oppressed is altogether damaging. The applied totality of the prison experience compromises any of the good intentions that may have been included in the plans of social engineers and the legislators who pour good money after bad in the pursuit of a correctional pipe dream. Cages that are restraining people inside a mean spirited prison system staffed with unaccountable prison workers can never reform people nor can they rehabilitate anyone. The Quaker Committee on Jails and Justice when making submissions to the Parliamentary Standing Committee on Justice and Legal Affairs stated:

Positive growth cannot occur in an environment where one has minimal rights and responsibilities, no freedom of choice and is denied normal human contact. There are few substantial trade programs, little or no effective schooling available, and no opportunity to grow and develop as a responsible citizen (MacGuigan, 1976).

When I have made this argument before, some people have asked me to explain the dichotomy in relation to my personal growth and education 
while in the prison system! I believe that my personality type, which apparently lends itself well to managing adversity, is able to thrive under pressure. It is my observation and experience that this is not the experience of the vast majority of people.

\section{Personal Experience}

All available evidence demonstrates that educational upgrading, even in prison, results in increased self-esteem, critical thinking and selfdiscipline. These personal gains combine to reduce the likelihood of a released prisoner coming back in conflict with the law (Porporino and Robinson, 1992). It is apparent that this result may occur because the 'educated' person is more able to effectively look for and secure employment, and generally is more likely to feel socially viable and useful to others, perhaps developing a sense of purpose. Yet without any rational explanation, CSC has reduced educational opportunities for those prisoners who desire it and to add insult to injury, it forces remedial educational processes on those imprisoned adults who do not wish it. This creates the misleading impression that CSC is promoting and facilitating education. I have observed that CSC wields mandatory minimum education levels as a tool to punish prisoners and as a method to artificially raise people's security levels.

Prior to my forced exile, I had received a Grade 8 education so I had little in the way of academic training or experience. I had always been in trouble at school and that left me with a clear dislike of the school atmosphere. At the beginning of my sentence, I was incarcerated in the Special Handling Unit (SHU) and they offered a "pilot project" art course to prisoners in "phase II". ${ }^{5}$ I tried to enrol, but was denied access. I presume the reason - and I was told several - was because I was an administrative nuisance. When I was let out of the SHU, four Christmas' later I had developed - learnt - a troubling verbal stammer and at times every thought would vacate my mind, unable to recall what I was thinking about. This was likely due to years of social isolation and little verbal communication. People respond differently to stressful events. At any rate, I was later released from the SHU on probation to Millhaven Penitentiary, a maximum security prison. One of the lessons I learnt was that CSC wanted to perpetuate the aura of danger, both through insinuation and the actual applied label - teach people what is expected and they often oblige. I enrolled in school because I wanted - needed - to do something constructive with my time. I wanted to make sure that I would avail myself of any opportunities in these gulags, these 
treacherous human warehouses. CSC allowed me to attend school. I was given a mandated course of studies, which I completed and eventually earned my high school equivalency. I signed-up for a university Political Science course, but soon found myself discouraged with the prospect of only being permitted one course per semester, which I felt would take forever - apparently, I was not clear on my sentence parameters. I did not foresee being able to apply Political Science to any aspect of my life - clearly another example of my uncanny ability to misread the future. In retrospect, I imagine that course of studies would have been amazingly useful to the role I appear to have assigned myself - Justice Critic to a party of one! In any event, I wanted to do something I actually liked while my eternal punishment gently squeezed the life out of me.

I was still interested in art and started reading books on the subject. I was soon through all of the books in the library and I had set my sights on formal art instruction, which I quickly realized was sparse at best. I started writing to all the schools, colleges and universities in Canada asking if they would help me. After all, who does not want to help a prisoner... right? I asked if they would set up a curriculum that I could follow from inside a cell. To be fair, I did get a great response from the Ottawa School of Art, which indicated they would set up a curriculum especially for me, but it seemed too complicated due to red tape from the prison. Eventually, I ended-up finding a course outline which was available through correspondence and I applied to take the courses.

The official response to my art courses request was NO! The prison bureaucrats explained to me that art, much like music, was not educational and amounted to a waste of time. Discussions with them illuminated that this position was predicated on the "if you enjoy it you cannot be learning anything of value" principle, an argument which quite effectively illuminates their essentially faulty rationale. I began to write letters, complain, file grievances and eventually through a stubborn refusal to giveup coupled with the intervention of Anglican Bishop Duncan Abrahams from Saint James Cathedral in Toronto, I was successful. I had the good fortune of meeting the Bishop through coincidence. When a friend and fellow prisoner was being visited by Bishop Duncan Abrahams, I spoke to him. He inquired about what was going on and I told him. He saw something in me that he felt was redeemable (his words), wrote to the prison administrators and sent CSC half the funds for the courses. Under that kind of pressure, CSC yielded and allowed me to enrol. That whole process took about two or three years from request to authorization.

Having capitulated in no way meant CSC were finished hassling me about art, a technique favoured by administrators when prisoners are 
perceived as going against the grain. In point of fact, they hindered and stalled my progress through the courses in a rotating war of attrition by confiscating all my art supplies and course materials. They also prevented me from buying needed art supplies and in the process of involuntarily transferring me, lost or destroyed my school materials and even stole my artwork. For context, during the passage of time in which I was trying to complete the course of studies I had been (voluntarily) transferred to Joyceville Penitentiary, a medium security prison. Then due to allegations of wrongdoing, ${ }^{6}$ I was shipped back to Millhaven. Twice I brought CSC to court over the transfer and before a second hearing could commence they shipped me to Collins Bay, a medium security prison, in order to avoid being ordered to do so by the courts. From this exercise, I learnt that CSC operates as a law unto itself.

An art course outline that should have taken a couple of years to complete took me from 1990 till 1998. I received my Honours Diploma in Graphic, Commercial and Fine Arts. While suitably intoxicated with my hard won accomplishment and believing - for some inexplicable reason - that my efforts would be acknowledged by CSC as evidence of my commitment to turn my life around, I applied for a transfer down in security. And I learnt that if something is not their idea then it is simply meaningless to them.

\section{Marketable Skills}

My transfer application initiated a Risk Assessment process and I was assessed by psychometrist Rob Rowe, who among many other things asked me what I now wanted to do having just completed the art courses. I told him I was thinking about taking a health and nutrition course. He advised me that this would indicate that I lacked focus. Following his lead, I asked him what I should do. He told me I should try to sell my artwork and thereby prove I now possessed a marketable skill. I understood this to mean that he felt that to have value, art must be traded as a commodity or product in accordance with the capitalist's perspective. I knew I was being patronized and in the process of my success or failure, the system would be able to delay any movement in my case. Mr. Rowe indicated that this business pursuit would reduce my risk to society and make me a more viable candidate for lower security. Through this I learnt that I was not going to minimum security - that was ten years ago and I am still in a medium security prison.

I knew a business venture would be a huge source of problems for me and if I did not follow his direction, he or one of, if not all of 
his counterparts in future psychological assessments would say I did not - could not or would not - follow direction or that I demonstrated resistance, and consequently, I would never be considered a "good" or "manageable" risk for lower security. I found myself introduced to another catch-22 situation. No matter what path I chose I would get the short end of the stick. If I followed his direction, I would meet all kinds of hostility, resistance and problems from the prison administration. If I did not follow his direction, reports from psychologists would define and redefine my inability to follow his direction. Thereby, I learnt I would not be going down in security.

I knew that the prison system did not approve of art as a viable educational pursuit and they would certainly not embrace me running an art business. I had to tread carefully, slowly. I sought out reference material on small business management and I got in touch with a small business start up group (SBS). ${ }^{7}$ The SBS helped me refine my business proposal and even provided a business start up mentor. Soon Jim Purdie, a retired business professor and concerned social activist, was put in touch with me by the SBS. Jim was a really nice and amazing person. With his help, I developed a great business plan. The administration eventually capitulated and permitted me to run the business. In reality, CSC had no intention to allow it (me) to succeed, but they wanted to appear as if they had given me the opportunity. CSC placed insurmountable hurdles in front of me and made it impossible to accomplish anything. They created a censorship board specifically for my cartoons and political work. That censorship board ${ }^{8}$ is still in place today, although they long since disbanded my business - apparently they have to keep control of my art. However, it was not all a waste of time. I learnt many skills and small business insight. Most importantly, Jim and I remain friends. I also learnt that CSC was more interested in denying real opportunities than they were in helping a prisoner develop the skills and tools to become a useful member of the community.

For additional context, over the years of my incarceration I have earned certification as a Frontier College ESL Tutor, I am a certified Alternatives to Violence Project (AVP) Facilitator, a certified Peer Education Counsellor and have been working as a HIV/AIDS counsellor for eight years with excellent - albeit, absolutely meaningless - work reports from my supervisor and case management team. I have received written offers of employment upon release from the Canadian HIV/AIDS Legal Network, the Prisoners with HIV/AIDS Support Action Network (PASAN), ${ }^{9}$ The Irish Penal Reform Trust and Rittenhouse as a result of my committed volunteer work which I have performed for these agencies 
over the last decade. I have co-authored HIV/AIDS harm reduction documents that have been used in prison health and safety education, and training seminars around the world by Rick Lines and other UNAIDS representatives. I was recently awarded the 2008 Canadian Award for Action on HIV/AIDS and Human Rights, an award presented by Human Rights Watch and the Canadian HIV/AIDS Legal Network for my ongoing efforts around the HIV/AIDS crisis in the prison system. My artwork and writing has been published in a variety of venues for a multitude of purposes (educational, promotional, letterheads, pamphlets, cards and so on) and I continue to donate all my considerable - at least in volume - artwork to charities. In spite of all my efforts and the very clear development of "marketable" skills to everyone but CSC, ${ }^{10}$ my "Correctional Treatment Plan" records me as having considerable difficulty with employment. The "considerable difficulty" designation allows the federal prison authorities to keep my security status raised.

\section{Imposing And Restricting Education as Punishment}

Correctional Service of Canada demonstrates in many ways that they do not value or support higher learning (CSC, 1999) $)^{11}$ and they continue to use mandatory education levels to force unwilling prisoners to attend prison schools, or stay in prison longer, regardless of their situation. The person may, for many varied reasons, not wish or need to attend school, but regardless they are forced into school. In these cases, the prisoner is not even permitted to take a test to receive a General Equivalency Diploma (GED) and in this way CSC creates an oppressive atmosphere in the school with disgruntled prisoners who interpret prison schooling as a forced punishment, and the ensuing resistance to education is purposely cultivated by the organization. Currently, CSC is preventing prisoners from engaging in academic upgrading by correspondence in their evening hours in their cells, which is preferred by prisoners who cannot work in or do not wish to attend the school area of the prison. If and when prisoners fail or refuse to attend school, then their security rating increases as their education is tied into their mandatory "Correctional Treatment Plan". Some prisoners may never be academically motivated, but if CSC continues to force unwilling people into engaging in abstract academic pursuits which have no apparent use or context to someone's life, then the organization along with the prisoner can and will almost always be assured of failure. It can be argued here that CSC's conduct exemplifies Reiman's (2004) argument in "The Rich Get Richer and the Poor Get Prison", where he suggests that the apparent failures of the 
system are actually successes according to its unspoken logic of coercion, repression and self-perpetuation. If CSC actually created a system of education around trades or skill pursuits that directly relate to tangible employment opportunities and marketable skills then they would invoke a motivation and commitment to learning because prisoners would see that their work, the effort and the result will actually benefit them, but that does not appear on any horizon line.

\section{Historical Retrospective}

Since we have gone back a quarter century, I thought we could go back a little further to briefly review the conduct of our prison administrators. In 1835, Kingston Penitentiary opened, and forced total silence and seclusion with hard labour. Isolation, solitude, congregation and labour under a system of silence are indicative of the "Auburn System" (Beattie, 1977). These were the days of provincial and continental banishment and transportation to New South Wales and Van Diemans Land (Tasmania) as punishment, where many "transported" prisoners did not survive the 18 week sea journey. In 1933, as a result of changes to penitentiary regulations prisoners who worked in offices or workshops were - at times - permitted a half hour outside in the fresh air. In 1945, the rule of imposed silence was relaxed and prisoners were allowed to speak to each other during meal time and in their cells until 7:00pm. In the late 1940s, prisoners also began to be allowed to take higher education courses through correspondence at their own expense and families could provide prisoners books. It should be strenuously noted that in this day and age of 2008, families are not permitted to send prisoners educational books and CSC libraries are dismal. The prisons were very harsh environments that employed many atrocities such as the practice of hand cuffing prisoners to bars all day, putting the ball-and-chain on their legs during hard labour work periods or dunking them in troughs of ice and slush as "mental health care treatment". Electroshock and physical beatings with whips and straps were gradually rescinded, as lights were placed outside some cells to allow "well behaved" prisoners to read at night. Prisoners were allowed to write one letter to family every three-month period. It is fair to note that electroshock, and three, four and five point binding ${ }^{12}$ still goes on today under the guise of mental health care.

After a couple riots and incidents, the Parliament commenced the Royal Commission which resulted in the 1938 Archambault Report and recommendations of greater "constructive application of recreation in the treatment" of prisoners. Prisoners were permitted to walk in pairs and 
talk to each other. Competitive sports were introduced and prisoners even competed with outside leagues - something that has been abandoned by $\mathrm{CSC}$ in this day and age. Correspondence restrictions were removed and visits were allowed. Hobby activities were recognized as occupational therapy - something CSC actively discourages by hindrance and attrition today.

In 1959, the Minister of Justice assigned Allan J. MacLeod, Q.C., to study the Penitentiary System. The MacLeod Committee produced its report in 1960 and it became the blue print for prison reforms. MacLeod was appointed commissioner and he announced an end to "soul destroying" work, long lock-up, and prisons existing in secrecy and isolation from the community. He warned guards that if they did not like the changes that they should find new work. Many changes occurred, but the enduring reality of soul destroying prisons and secretive prisons remain ever-present. Canada has essentially exchanged physical beatings and torture for long-term psychological torture with some of the longest sentences in the world coupled with some of the most restrictive, and arbitrary parole and release mechanisms. The "peace" or "correctional officer" faction of the Public Service Alliance of Canada (PSAC), ${ }^{13}$ which became a recognized union in 1967, has always resisted and undermined progressive changes. Over the years, this branch of PSAC has become effective at appearing forthright and concerned with public safety, while concealing its less than admirable intentions for the purpose of achieving its ideological backward and repressive goals. However, during the late 1970s and early 1980s, there was a generally more inclined political will and vocal public pressure ${ }^{14}$ to avoid repeating prison failures of the past. In 1976, the MacGuigan Parliamentary Report (paragraphs 78-80) stated:

Prisons as they now exist, protect society only during the $2,3,10$ or 20 years the inmate is in there; but if the institutions are boring, oppressive and lack programs preparing inmates for release, they come out angry, vindictive, frustrated, snarling like animals released from long confinement in a cage... Most of those in prisons are not dangerous. However, cruel lockups, isolation, the injustices and harassment deliberately inflicted on prisoners unable to fight back, make non-violent inmates violent, and those already dangerous more dangerous.

The MacGuigan Report produced some pressure and some change. By the late 1980s, there was a fleshing out of the base level skills training programs. The availability of educational opportunities providing prisoners with access to high school and university courses, as well as skills and 
trades training with the opportunities to receive a ticket and/or recognized certification in mechanics, electrical service, barbering, painting, carpentry, among others increased. In the 1990s, with the introduction of a progressive Scandinavian Commissioner of Corrections, Ole Ingstrup, CSC experienced significant growing pains upon the introduction of the Corrections and Conditional Release Act (1992, C-20) ${ }^{15}$. Ingstrup tried to make progressive changes occur through the introduction of the CSC Mission Statement, but PSAC and bureaucrats within the organization resisted the changes at the ground level. Eventually through attrition, PSAC was able to capitalize on Canada's waning political will and forced the Commissioner's resignation. PSAC's coup heralded a pronounced, albeit gradual, reduction in educational opportunities and skilled labour training which was replaced by "life skills"16 programming and the "CORCAN"17 industries, both of which are very expensive façades for education and skills training. The reality is that life skills programming is very sparse and often ineffective for a variety of reasons ${ }^{18}$ - I have been provided a total of nine weeks over a quarter century.

With regard to the CORCAN industries, usually only one or two prisoners out of each prison are taught marketable skills or earn credentials, and this appears to serve the purpose of exploitation. It is cost and labour effective for the CORCAN industrial plants to train one or two prisoners to perform those few jobs that require dedication, expertise and willingness to work. When CORCAN staffing compliment delegate prisoners to perform these jobs, it permits the staff to take a passive role and essentially get their money for nothing. Aside from the exploitive agenda driven sharing of skills there is nothing going on in CORCAN sweatshops that provide prisoners with useful marketable skills. The vast majority of CORCAN employment is assembly line component manufacturing that is often outdated. However, because the CSC CORCAN employment scheme pays prisoners at higher rates than usual prison jobs, many prisoners either do not see or overlook their exploitation in exchange for additional pennies. Poverty is a powerful motivator. While operating as a sheltered workshop for the prisonindustrial complex, CORCAN operates as a financial sink hole through which tax payers are thoroughly gouged.

We are almost at 2010, and CSC has fully eradicated all meaningful employment training and release preparation. It also has a meagre amount of their considerable resources directed towards prisoner life skills programs which most prisoners express did not aid them whatsoever for community living. The reality is that $\mathrm{CSC}$ has a program availability shortfall. Overcrowding in Canadian prisons continues to increase, at least 
in part, due to the constant failure to place sufficient financial resources into providing CSC mandated pre-release programming to prisoners and thereby holding prisoners past parole eligibility release dates. It should be noted that CSC has never complied with legislated mandates to have programming available for prisoners prior to their reaching parole eligibility dates. While CSC continues to cite non-compliance by prisoners or funding shortfalls to explain programming non-completion or unavailability, the reality is CSC chooses not to designate the required and available monies to programming targets which would according to their own stated beliefs and policies most effectively address prisoner's $\mathrm{CSC}$ imposed correctional treatment and reintegration needs. As a result, parole release timelines are unnecessarily lengthened.

In 1996, the Auditor General devoted a chapter of his fall report to Parliament on this topic detailing several areas in which CSC needed improvement. It is now 12 years after the fact and prisoners still arrive at parole eligibility dates without having had the opportunity to complete their mandated programs. The Auditor General's review of CSC's failure to properly prepare prisoners for their parole eligibility dates went unheeded, as the organization continues to "splurge spend" fiscal year end surpluses with ridiculous make work and spend money projects. CSC continues to engage in redundant top heavy administrative spending while designating proportionally small amounts toward prisoner education, core correctional-substance-rehabilitation programming and release preparation, as well as community reintegration planning.

\section{So What Have We Learnt?}

Underestimating the negative impacts of a life full of endlessly imposed deprivation is a social mistake that we need not repeatedly make. Whether the deprivation is in equality, acceptance, love, family, normal relationships, sexual contact, education, employment or reasonable financial compensation, or a sense of purpose, freedom or fair treatment under the law, or whatever needs, wants and desires the human condition experiences, the result heightens the individual's push, pull or drive towards "it". The deprivation in itself cultivates, embellishes and tightly focuses the desire, the need, and the want. Thus, it is reasonable to assume that the longer deprivation is imposed the more pronounced the negative impacts on the individual, the family and the community, and thereby the more likely public safety is compromised. One of the defining hallmarks of CSC's failure to produce positive results is their inability to look outside their narrow minded and short-sighted field of vision. It 
is their petty, and corrupt perspective that dooms all of their official and very expensive endeavours to failure.

Prisoners pay a serious price for speaking critically about CSC practices. Most prisoners keep their heads down and their voices silent because they are cowed into silence. I am also painfully aware of a "correctional" variation of the Stockholm Syndrome ${ }^{19}$ which contributes to diminished critical resistance form prisoners. CSC seeks silence from prisoners because it makes their jobs easier and their short-term goals are more easily reached. I have learnt that in the long-run and shortrun what happens in prisons compromises the long and short-term mental, emotional, and physical health and safety of prisoners, prisoner's families, prison guards and society. It appears that most prisoners and most of the public accept whatever the CSC says as the inevitable truth or the inevitable way of the world. However, forced subservience under lock and key is missing the point.

\section{ENDNOTES}

1 It has been noted that I engage in anthropomorphism by inputting human behaviour to abstract processes or concepts - specifically to the prison system. It was suggested that some of my concepts become a bit mixed as a result. I am unsure how to do a better job on this area. I have come to understand that many prison workers simply become extensions of the system in deed and spirit. Their thoughts and therefore their decisions are not their own. They simply do what they have learnt is the accepted standard operating procedure within the prison-industrial complex.

2 "The Hole" is a punitive isolation cage, usually dark or endlessly bright.

3 A federal crime committee appointed by the Mulroney Conservative Government.

4 The Stanford Experiment was conducted by having students take on the roles of prisoners and guards, while being monitored for behavioural changes. The students sunk into their respective roles and the experiment had to be terminated due to the danger level the experiment exhibited. The prisoners and guards had become dangerous, abusive, violent and suicidal.

5 The phase systems consisted of 4 phases: 1) twenty three and a half hour lockup with yard by yourself; 2) increased time in the yard with a limited number of others; 3 ) increased time out of your cell; and 4) probation in a maximum prison - usually took years to get through it.

$6 \quad$ I had filed a complaint of theft against a guard who stole five cartons of cigarettes out of my cell. The following day, I was placed on a restricted diet that provided five hundred calories a day and I lost thirty pounds. Then the prison accused me of using heroin and cocaine thereby explaining my weight loss, dealing drugs, beating people up, running a crime ring and murdering a fellow prisoner - all of which proved to be false allegations. CSC apologized in writing for starving 
me and returned my cigarettes, but by this time I was in Millhaven maximum security.

7 Opportunities in Kingston is a small business start up group that operates in the community which receives federal, provincial and local government assistance.

8 The censorship board was headed by my case management officer and he would never meet with me.

9 Prisoners with HIV/AIDS Support Action Network (PASAN) is an agency that works with HIV positive prisoners trying to ensure they are receiving appropriate medical treatment, and assistance in prison and upon release.

10 "Marketable Skills" is only a term I use because they use it - I would prefer to characterize it as "useful skills".

11 CSC fails to provide any funding for post-secondary education.

12 "Binding" is the practice of using straps or handcuffs, restraining beds and chairs to immobilize prisoners, which has resulted in many deaths.

13 The branch of PSAC that deals with prisons falls under the purview of the Department of Public Safety - see www.psac.com.

14 It is clear that activists like Claire Culhane, Prisoners Rights Group, and academic discussions championed the cause of the prisoner and reluctantly to make a significant pressure. It is also clear that the combined pressure has waned for a variety of reasons. A couple of clear factors are: 1) the passing of Claire Culhane; 2) the increased sophistication of PSAC, police associations and victim's groups; and 3 ) the criminalization of protesters.

15 The Corrections and Conditional Release Act (CCRA) is legislation that CSC continues to repeatedly undermine and ignore with impunity.

16 Life Skills Programming (for the purposes of this paper) includes programs dedicated to the wide variety complex problems that are faced by people such as, but not limited to: 1) Alcohol \& Drug Addiction; 2) Sexual Conduct; 3) Violence; 4) Cognitive Reasoning; 5) Employment; and 6) Friends \& Associates.

17 CORCAN is an acronym for Correctional Service of Canada - http://www.cscscc.gc.ca/text/prgrm/corcan/operations-eng.shtml.

18 Program participation is coerced and delivered by prison staff that often lack meaningful program subject insight or lack credibility with prisoners. Programs are of short duration with little to no follow-up or facilities to practice learnt concepts.

19 Stockholm Syndrome occurs when individuals identify with, and develop trust and affection for their captors.

\section{REFERENCES}

Archambault, Hon. Joseph (1938) Report on the Royal Commission to Investigate the Penal System of Canada, Ottawa: Queen's Printer.

Auditor General of Canada (1996) "Chapter 30 - Correctional Services Canada Reintegration of Offenders", in Report of the Auditor General of Canada, http:// www.oag-brg.gc.ca/inkrnct/english/pan-org199611.30-c-5061.html.

Beattie, J.M. (1977) Attitudes Toward Crime and Punishment in Upper Canada, 
1830-1850, Toronto: Centre of Criminology, University of Toronto.

Correctional Service of Canada (1999) Commissioner's Directive Number 720: Education of Offenders, Ottawa.

Daubney, David (1988) Taking Responsibility: Report of the Standing Committee on Justice and Solicitor General on its Review of Sentencing, Conditional Release and Related Aspects of Corrections, Ottawa: Queens's Printer for Canada.

Goffman, Erving (1963) Stigma: Notes on the Management of Spoiled Identity, Englewood: Prentice-Hall.

Hare, Robert (1970) Psychopathy: Theory and Research, New York: Wiley.

Hart, Stephen, Christine Michie and David J. Cooke (2007) "Precision of Actuarial Risk Management Instruments: Evaluating the 'Margins of Error' of Group v. Individual Predictions of Violence", British Journal of Psychiatry, 190: s60-s65.

MacGuigan, Hon. Mark (1976) Report to Parliament, The Sub Committee on the Penitentiary System in Canada - Standing Committee on Justice and Legal Affairs, Ottawa: Queen's Printer.

Maden, Anthony (2003) "Standardized Risk Assessment: Why All the Fuss?", Psychiatry Bulletin, 27: 201-204.

Porporino, Frank J. and David Robinson (1992) "Can Educating Adult Offenders Counteract Recidivism?", Forum on Corrections, Ottawa: Correctional Service of Canada, R-22.

Reiman, Jeffrey (2004) The Rich Get Richer and The Poor Get Prison: Ideology, Class, and Criminal Justice (seventh edition), Toronto: Pearson.

Whittington, Les (2008) “Harper Rejects 'ivory tower' criticism: Says sociologists, criminologists who criticize his get-tough-on-crime proposals have been soft on crime for years", The Toronto Star, http://www.thestar.com/printArticle/ 504317 - September 23.

Zimbardo, Philip (2008) The Lucifer Effect: How Good People Turn Evil, New York: Random House.

\section{About the Author}

Serving a life sentence in prison, Peter Collins knew he had to come to terms with the consequences of his actions and so dedicated himself to working for positive social change. Since the late 1980s, when the official position of the Correctional Service of Canada was that intravenous drug use, tattooing, and sex were illegal - therefore not happening - until today when prisoners continue to be denied access to clean needles and syringes, Peter's tireless efforts to defend the health and human rights of prisoners have often led to strained relationships with prison officials, undermining his efforts to get paroled. While in prison, Peter earned an honours diploma in Graphic and Commercial Fine Arts, as well as a certification as a Frontier College ESL tutor. He is an Alternatives to Violence Project facilitator and Peer Education Counsellor. Peter was 
instrumental in setting up a Peer Education Office in his prison and has advocated on behalf of fellow prisoners on issues ranging from health access to employment. He also wrote a book helping prisoners prepare for successful and safe release into the community. Regularly donating his time, expertise, and artwork to numerous charities and social justice initiatives, Peter's dedication has contributed to improved health and safety in the prison system, and by extension, in the community at large. 